\title{
28. PALYNOLOGY OF DEEP-SEA CORES FROM DSDP SITE 275, SOUTHEAST CAMPBELL PLATEAU
}

\author{
Graeme J. Wilson, New Zealand Geological Survey, Lower Hutt, New Zealand
}

\section{INTRODUCTION}

Site $275\left(50^{\circ} 26^{\prime} \mathrm{S}, 176^{\circ} 19^{\prime} \mathrm{E}\right)$ is located near the southeast margin of the Campbell Plateau about $600 \mathrm{~km}$ southeast of New Zealand and the same distance eastnortheast of Campbell Island (Figure 1). The present depth of the sea floor is 2800 meters. Five cores were recovered from the site with a total penetration of 62 meters. Core 1 (4 samples), Core 2 (6 samples), Core 4 (1 sample), and Core 5 (1 sample) were examined for palynomorphs.

The stratigraphic succession has been dated as Late Cretaceous (Chapter 2, this volume) and divided into two main lithological units, which are covered by a thin veneer of foraminiferal ooze and manganese nodules, of Pleistocene age. The upper unit (Unit 1) is comprised of a pale yellow and olive, soft, moderate to intense mottled sandy silt and glauconite-rich radiolarian diatom ooze. This includes all of Core 1 and all except the base of Core 2. Unit 2 is a dark olive-gray massive stiff, glauconite and nodule-bearing detrital clay silt. This unit includes the lowest section, Sample 2, CC, and all of Cores 3, 4, and 5. A sharp contact separates Units 1 and 2.

Samples of ca $15-20 \mathrm{~g}$ were processed by using a standard HF/oxidation/flotation technique. Residues were mounted in safranin glycerine jelly.

Slides are located in the collections of the Palynology Section, New Zealand Geological Survey, Lower Hutt, under catalog No. L6424-L6435.

\section{RESULTS}

\section{Core 1}

All four samples from Core 1 are barren.

\section{Core 2}

The upper sample from Core $2(275-2-1,70 \mathrm{~cm})$ contains very sparse assemblages of miospores including Beaupreaidites elegansiformis which almost certainly indicates a Late Cretaceous age. Pollen species include Nothofagidites (brassi group), Nothofagidites (fusca group), and several species of conifer pollen. Very rare specimens of dinoflagellate cysts occur including: Spinidinium cf. aperturum Wilson, Deflandrea phosphoritica Eisenack, Deflandrea macmurdoensis Wilson, and Areosphaeridium dictyoplokus (Klumpp). It is probable that all are contaminants from Eocene rocks, possibly residual material from earlier cores since E. M. Kemp (personal communication) recorded similar species from the lowest samples of Core 274 (Leg 28).

Three samples from the middle part of Core 2 (Sections 2, 3, 4) are barren.

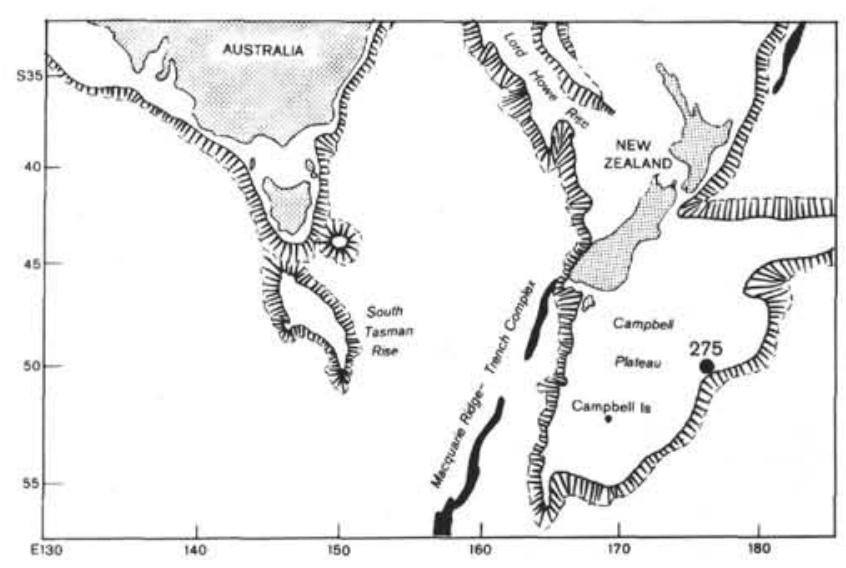

Figure 1. Location of Site 275, DSDP, Leg 29.

The lowermost sample from Core $2(275-2-6,80 \mathrm{~cm})$, belonging to the top of Unit 2, contains an excellent assemblage which can be correlated with the New Zealand Haumurian Stage (approximately equivalent to the uppermost Campanian and Maestrichtian). Both miospores and dinoflagellate cysts are abundant and are represented by a total of over 35 species. The dinoflagellate assemblage is very similar to that recorded by this author from the Garden Cove Formation of Campbell Island (Wilson, 1967), but is more diverse. Species common to the Garden Cove Formation include: Svalbardella aff. australina Cookson, Svalbardella granulata Wilson, Deflandrea cretacea Cookson, Spiniferites ramosus (Ehr.) "Leiosphaeridia ovata" Wilson, and the colonial alga Palambages morulosa $\mathrm{O}$. Wetzel. The age of the Campbell Island assemblage, formerly considered basal Tertiary, is now regarded as Late Cretaceous (Wilson, 1972). Other dinoflagellate cysts present in this interval include two species of Cladopyxidium, Exochosphaeridium cf. striolatum, Cleistosphaeridium, Spiniferites ramosus, Chlamydophorella sp., Areoligera aff. senonensis, Glyphanodinium sp., and a very distinctive spinulose species of Deflandrea common in the New Zealand Haumurian. Miospores are common and include Phyllocladidites mawsoni (restricted to the uppermost Cretaceous), Tricolpites lilliei, and Tricolpites waiparaensis (both restricted to the uppermost Cretaceous in New Zealand). Other miospores include abundant Podocarpidites, Microcachryidites cf. antarcticus, Lycopodiumsporites sp., triorate and tricolpate pollen, and indeterminate trilete spores. Plant cuticles and fragments are common. 


\section{Core 3}

No material from this core was available for palynological study.

\section{Core 4}

Relatively rich assemblages of dinoflagellate cysts and miospores were obtained and indicate a Haumurian age. Dinoflagellate cysts are dominated by Deflandrea cretacea. Other dinoflagellates include Cribroperidinium aff. orthoceras, Deflandrea acutula, Spiniferites cingulatus, Deflandrea sp. (spinulose), Svalbardella granulata, Deflandrea acutula, and an especially interesting large species of the characteristic Upper Cretaceous genus Dinogymnium, probably $D$. nelsonense Cookson. The Upper Cretaceous colonial alga Palambages morulosa is common. Miospores include the typical Upper Cretaceous species Beaupreaidites elegansiformis, Nothofagidites kaitangata, and Tricolpites lilliei; other species include Sphagnum sp., Microcachryidites antarcticus, Lycopodiumsporites sp., Podocarpidites spp. and rare Proteaceae. Plant cuticles and fragments are fairly common.

\section{Core 5}

Relatively rich, typical Upper Cretaceous assemblages of dinoflagellate cysts and miospores were obtained. Dinoflagellate cysts include Deflandrea cretacea, Svalbardella aff. australina, S. granulata, Fromea aff. amphora, Cribroperidinium aff. orthoceras, Spiniferites ramosus, $S$. cingulatus, Cleistosphaeridium sp., and Oligosphaeridium complex. One possible specimen of Odontochitina was observed. The colonial alga, Palambages morulosa is fairly common. Miospores include the two typical Late Cretaceous species Beaupreaidites elegansiformis and Tricolpites lilliei. Other miospores species include Proteacidites parvus Cookson (first New Zealand appearance Haumurian), Nothofagidites cf. kaitangata, Aequitriradites sp., Trilites spp., and numerous disaccate pollen species. Leaf cuticles and other plant fragments are moderately common.

\section{DISCUSSION}

Palynomorph assemblages from Site 275 are typical of New Zealand Haumurian (upper Campanian to Maestrichtian) assemblages and closely resemble those from the Late Cretaceous of Campbell Island. Some of the dinoflagellate species have hitherto been recorded only from these two regions, and this additional record from the southeast Campbell Plateau is of considerable interest. The age of the lowest core appears to be no older than Haumurian, since several of its dinoflagellates and pollen species are not known before that stage in New Zealand.

Although the samples from Unit 1 (i.e., all samples above 275-2-6) gave poor palynofloras, it seems unlikely that this unit is significantly younger. The presence of the Late Cretaceous species, Beaupreaidites elegansiformis, in the upper part of Core 2 precludes the possibility of a significantly younger age for this interval. The presence of a very small number of specimens of Eocene dinoflagellates in a lower sample of Unit 1 is almost certainly due to contamination.

Many of the palynomorph species occur in the type New Zealand Late Cretaceous section at Haumuri Bluffs, and it should be possible to accurately correlate Site 275 with the New Zealand Late Cretaceous sequence in due course.

The cuticle fragments, fibers, and other macroplant remains of terrestrial origin, together with the relatively high diversity of miospores, indicate that the depositional site was reasonably close to land. However, it was much further from land than that of the approximately coequal Garden Cove Formation of Campbell Island. In all samples, both the diversity and individual numbers of dinoflagellate cysts are greater than those for the miospores, although the totals are comparable, particularly in Cores 4 and 5 .

\section{ACKNOWLEDGMQNENTS}

I am grateful to James P. Kennett, Co-chief scientist of DSDP Leg 29, for giving me an opportunity to examine the cores, and A. R. Edwards, of the New Zealand Geological Survey, for helpful discussion. Miss M. Dickson of the New Zealand Geological Survey processed the samples.

\section{REFERENCES}

Wilson, G. J., 1967. Microplankton from the Garden Cove Formation, Campbell Island: New Zealand J. Bot., v. 5, p. 223-240.

1972. Age of the Garden Cove Formation, Campbell Island. In Notes from the New Zealand Geological Survey -7 (Paleontological): New Zealand J. Geol. Geophys., v. 15, p. 184-185. 



\section{PLATE 1}

Drawings of selected palynomorphs recovered from DSDP Site 275. (Magnification: $\times 750$ for Figures $1-7,9-12$ and $\times 450$ for Figure 8 .)

Figure 1 Dinogymnium cf. nelsonense (Cookson), Slide L6434/3.

Figure 2 Deflandrea cretacea Cookson, Slide L6434/3.

Figure 3 Deflandrea acutula Wilson, Slide L6434/3.

Figure $4 \quad$ Deflandrea sp., Slide L6433/4.

Figure 5 "Leiosphaeridia ovata" Wilson, Slide L6433/2.

Figure 6 Exochosphaeridium striolatum (Deflandre), Slide $\mathrm{L} 6433 / 2$.

Figure $7 \quad$ Tricolpites lilliei Couper, Slide L6435/3.

Figure 8 Svalbardella granulata Wilson, Slide L6433/4.

Figure 9 Nothofagidites kaitangata (TePunga), Slide L6434/3.

Figure 10 Beaupreaidites elegansiformis Cookson, Slide L6434/3.

Figure 11 Palambages morulosa O. Wetzel, Slide L6434/3.

Figure 12 Cribroperidinium aff. orthoceras (Eisenack), Slide L6434/1. 


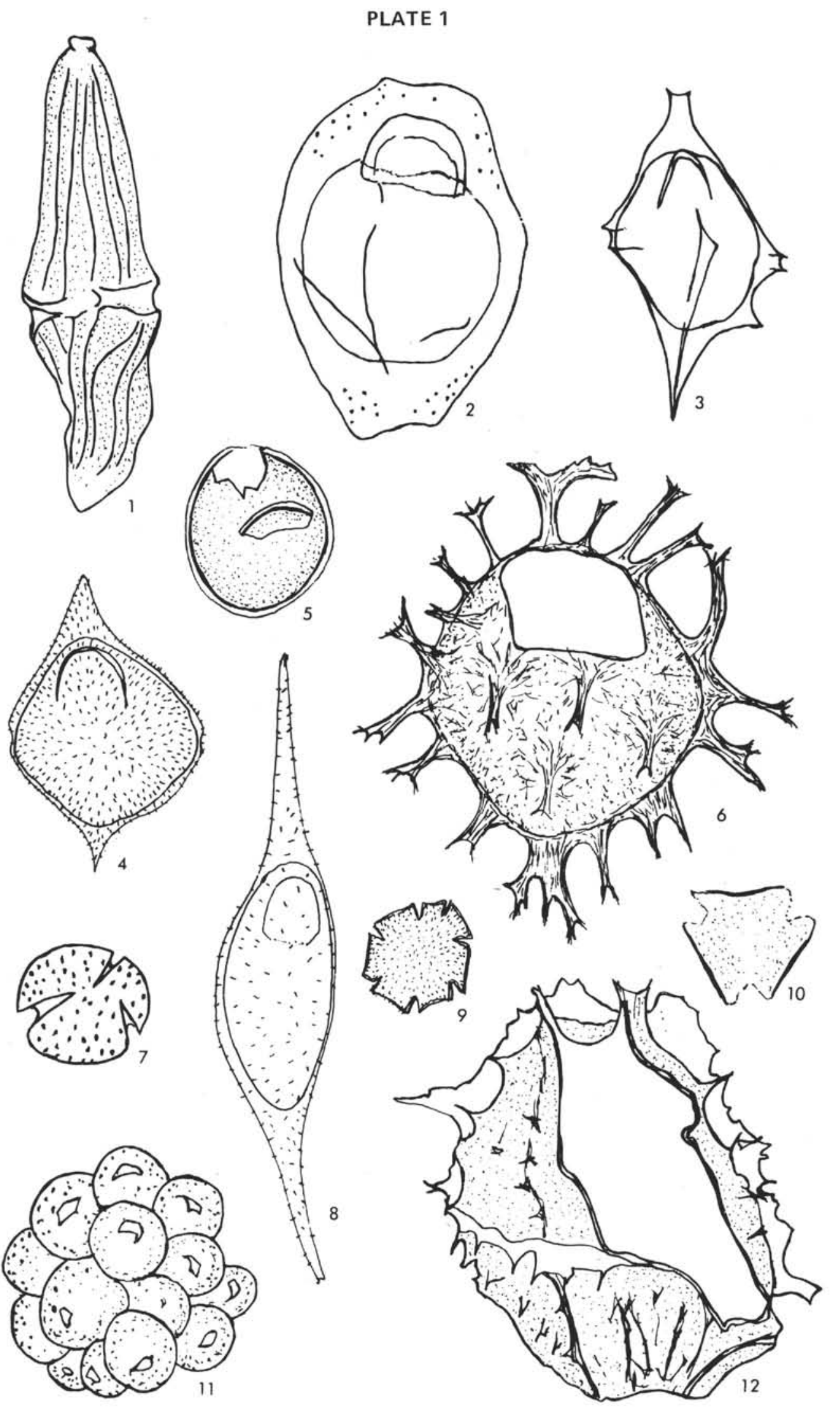

